\title{
Status of a second viable population of the Critically Endangered Delacour's langur in Viet Nam
}

\author{
Anh Tuan Nguren, Hoang Trinh-Dinh, Minh Le and Nguren Manh Ha
}

\begin{abstract}
One of the three Critically Endangered and endemic primate species in Viet Nam, Delacour's langur Trachypithecus delacouri, is restricted to the north of the country. The largest remaining population is in Van Long Nature Reserve, Ninh Binh Province, and the second largest is in nearby Kim Bang Protection Forest, Ha Nam Province, with other populations believed to be too small for recovery. The population in Van Long has been well studied but the status of that of Kim Bang has not previously been adequately evaluated. To address this, a survey was conducted during 10 August-7 October 2018. In total, we recorded 13 groups comprising a total of at least 73 individuals, almost doubling the highest number reported in previous studies. We documented six new groups in Lien Son and Ba Sao communes in Kim Bang. Our findings indicate there is a high likelihood that Delacour's langur population in Kim Bang will recover and could be important for the long-term conservation of this Critically Endangered species. However, immediate and appropriate conservation measures need to be implemented to protect the population from major anthropogenic threats, namely poaching and habitat destruction, detected during our survey.
\end{abstract}

Keywords Critically Endangered, Delacour's langur, population survey, Trachypithecus delacouri, Kim Bang Protection Forest, Viet Nam

There are 25 primate species in Viet Nam, more than 1 in any other mainland South-east Asian country (Blair et al., 2011; Roos et al., 2013). Of these, three are endemic and Critically Endangered, namely the Cat Ba langur Trachypithecus poliocephalus, Tonkin snub-nosed monkey Rhinopithecus avunculus, and Delacour's langur Trachypithecus delacouri (Roos et al., 2013; Covert et al., 2017). Delacour's langur is one of several species of the Trachypithecus francoisi group, which all occur in forest on

ANH TUAN NGUYeN* (Corresponding author, (1) orcid.org/0000-0001-6977-9970) and MinH Leł (10) orcid.org/0000-0002-2953-2815) Faculty of Environmental Science, University of Science, Vietnam National University, Hanoi, Viet Nam E-mail tuananhnguyen@hus.edu.vn

Hoang Trinh-Dinh ${ }^{*} \dagger$ and NguYen Manh Ha Center for Nature Conservation and Development, Viet Nam

${ }^{*}$ Contributed equally

$\dagger$ Also at: Fauna \& Flora International-Vietnam Programme, Viet Nam

¥Also at: Central Institute for Natural Resources and Environmental Studies,

Vietnam National University, Hanoi, Viet Nam

Received 22 July 2020. Revision requested 24 September 2020.

Accepted 10 March 2021. First published online 3 November 2021. karst limestone. The species is restricted to a small area of northern Viet Nam, formerly in remnant forest patches in the provinces of Hoa Binh, Ha Nam, Ninh Binh and Thanh Hoa (Nadler et al., 2003; Workman, 2010). The total number is estimated to be $250-300$ individuals in isolated populations occupying extremely fragmented forest patches (Nadler, 2015; Linh et al., 2019). Delacour's langur has been decimated by illegal hunting and habitat loss, with at least eight populations extirpated since 2000 (Workman, 2010; Nadler, 2015). The species is categorized as Critically Endangered on the IUCN Red List, and has been consistently ranked among the most threatened primates (Nadler et al., 2015; Schwitzer et al., 2015).

The largest known population of Delacour's langur is in Van Long Nature Reserve, Ninh Binh Province, with 176184 individuals (Linh et al., 2019). It was formerly considered the only viable population, with other populations thought too small for recovery (Nadler, 2015). Field surveys in the 1990 s by the Frankfurt Zoological Society (Nadler \& Long, 2001; Nadler et al., 2003) in Kim Bang Protection Forest, c. $15 \mathrm{~km}$ north of Van Long, revealed at least 20 langurs in 1-2 groups. In the early 2010s, a study confirmed one group of 4-5 individuals, and interviews reported up to seven groups with 24-32 animals (Nadler, 2015). In 2016, a survey by Fauna \& Flora International (FFI; Trinh-Dinh \& Le, 2016) recorded seven groups with a total of 40 langurs. The 2016 survey, however, covered $<50 \%$ of Kim Bang Protection Forest, and no surveys were carried out in the Lien Son and Ba Sao communes, which have well-preserved forests (Fig. 1). To assess the status of the langur population throughout Kim Bang, we conducted surveys and interviewed local people during 10 August-7 October 2018.

The Kim Bang Protection Forest is in eastern Kim Bang District, Ha Nam Province, and is managed by the commune authorities of Thanh Son, Lien Son and Ba Sao. Commune is the smallest administrative subdivision in Viet Nam; the population of each commune is 3,00010,000 people. The site covers c. 1,500 ha in the Red River Delta region (Fig. 1), characterized by dissected limestone karst formations and narrow valleys with fragmented patches of mature secondary forest on the ridges and upper slopes, and degraded forests with mostly scrub on the lower slopes (Trinh-Dinh \& Le, 2016). At present, the area is classified as local watershed protection forest, which means it is not a legally or nationally recognized protected area and has only a low level of protection from local law enforcement, which at least partly explains the degradation of the forest and the decline of Delacour's langur in this area (Trinh-Dinh \& Le, 


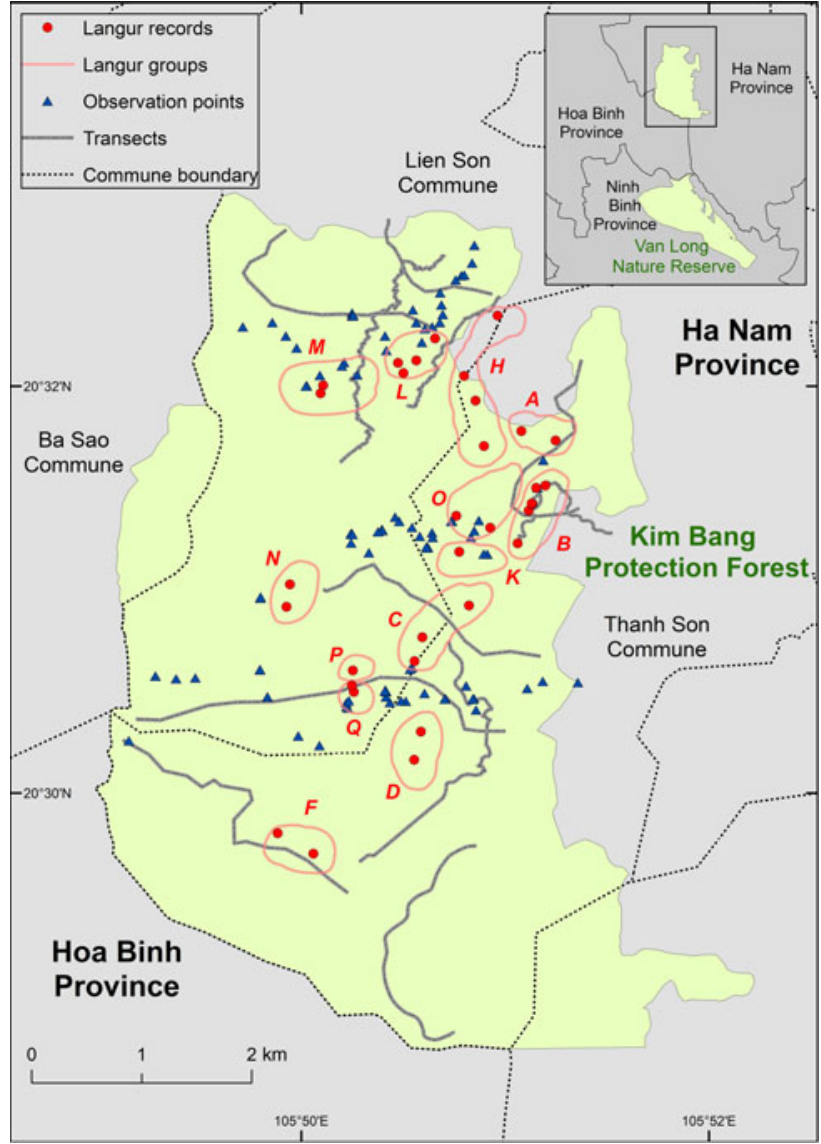

FIG. 1 Survey locations and observations of Delacour's langur Trachypithecus delacouri, with group names (Table 1), in Kim Bang Protection Forest, and, on the inset, the location of Van Long Nature Reserve, which holds the largest population of the species.

2016). However, the area has been proposed as a protected area for the conservation of Delacour's langur (Knight, 2019).

Prior to the surveys, we spoke with seven people in local communities who were knowledgeable about the Kim Bang forests, to identify potential survey areas and to select suitable locations for transects and observation points. We collected information on locations where langurs had been seen, dates of the observations, and group size and status. Transect walks and visual and auditory observations from fixed points were used to survey the langurs (Fig. 1). We used two teams of surveyors; a team included one researcher and 1-2 local guides. Each team walked separate transects and observed from independent points, to maximize detection probability. As the adult male of a langur group frequently emits loud calls, and often sits as a sentry on prominent features such as the top of a tree or rock (Workman, 2010), we established observation points and transects on high ground.

When langurs were spotted, we recorded time and date, geographical coordinates of the team, direction and estimated distance to the langurs, and group size and structure.
TABLE 1 Details of the groups and group sizes of Delacour's langur Trachypithecus delacouri in Kim Bang Protection Forest, Viet Nam. See Fig. 1 for additional information on the locations.

\begin{tabular}{|c|c|c|c|}
\hline $\begin{array}{l}\text { Group } \\
\text { name }\end{array}$ & $\begin{array}{l}\text { Minimum } \\
\text { group size }\end{array}$ & $\begin{array}{l}\text { Maximum } \\
\text { group size }\end{array}$ & Comments \\
\hline Group A & 7 & 7 & \\
\hline Group B & 11 & 12 & \\
\hline Group C & 6 & 6 & \\
\hline Group D & 4 & 6 & \\
\hline Group E & $?$ & $?$ & $\begin{array}{l}\text { Interview information } \\
\text { indicated four langurs, } \\
\text { but we were unable to } \\
\text { confirm their existence } \\
\text { during the survey }\end{array}$ \\
\hline Group F & 1 & 3 & \\
\hline Group G & $?$ & $?$ & $\begin{array}{l}\text { Interview information } \\
\text { indicated two langurs, } \\
\text { but we were unable to } \\
\text { confirm their existence } \\
\text { during the survey }\end{array}$ \\
\hline Group H & 8 & 8 & \\
\hline Group K & 3 & 6 & \\
\hline Group L & 11 & 12 & \\
\hline Group M & 1 & $?$ & $\begin{array}{l}\text { Only one individual } \\
\text { observed, but local people } \\
\text { reported up to } 16 \text { indi- } \\
\text { viduals in this group }\end{array}$ \\
\hline Group N & 6 & 6 & \\
\hline Group O & 12 & 12 & \\
\hline Group P & 1 & $?$ & $\begin{array}{l}\text { Only one individual ob- } \\
\text { served, but local people } \\
\text { reported up to six indi- } \\
\text { viduals in this group }\end{array}$ \\
\hline Group Q & 2 & 2 & \\
\hline Total & 73 & $82-97$ & \\
\hline
\end{tabular}

The age-sex classification (adult male, adult female, juvenile, infant), followed Nadler et al. (2003) and Workman (2010). We took photographs and videos of langurs and their habitat whenever possible. To avoid double counting langur groups that travelled extensively in one day, the teams compared time and location of observations, and group size and composition, at the end of each day. Any groups that could not be clearly distinguished were treated as a single group. When there were different counts for the same group, we retained both estimates (Table 1).

We recorded 13 groups and a total of at least 73 individuals (Fig. 1, Table 1), almost doubling the highest number reported in previous surveys, and including six new groups in the extended survey area. The population size could be greater, as we did not include one potential group with at least 4-6 individuals (Group P) and another with $>10$ individuals (Group $\mathrm{M}$ ) in the final tally. We were also unable to confirm the existence of two additional groups reported during the interviews (Groups E and G). Future studies should focus on these four groups. 
Our conversations with local people and our observations during the survey indicated that the greatest threats to Delacour's langur in Kim Bang are poaching and habitat degradation. We detected snares and leg-hold traps in the protection forest, and a dead langur entangled in a snare. Hunting with handmade rifles, although illegal, still occurs in Kim Bang, and we saw signs of such activities (makeshift gun primers and shells) in the forest. On the eastern side of the forest, seven companies were quarrying limestone on the karst outcrop the langurs inhabit. Given the scale of the mining, we expect the available habitat for Delacour's langur will be reduced substantially.

Although the Kim Bang Protection Forest has the second largest remaining, viable population of Delacour's langur, the site has received less attention than that of Van Long, and therefore we do not know whether the population in Kim Bang has declined, although this is likely, given the existing threats. Nonetheless, the Delacour's langur population in Kim Bang could potentially recover if appropriate conservation measures are implemented in the near future. In 2020, monitoring teams supported by FFI and the Center for Nature Conservation and Development discovered evidence of recruitment, with several infants observed (H. Trinh-Dinh, pers. obs., 2020).

As Delacour's langur has disappeared from much of its former range (Nadler et al., 2003; Nadler, 2015), the future of the species depends primarily on the two largest populations. Given their proximity, the establishment of a biological corridor to connect them would be beneficial for the long-term conservation of this Critically Endangered species. Our findings will inform the proposed gazettement of a new protected area in Kim Bang, and will form the baseline for future monitoring of this langur population. In September 2020, an emergency proposal, including the designation of a new Species and Habitat Conservation Area in Kim Bang, signed by FFI, the Center for Nature Conservation and Development, WWF-Viet Nam, the IUCN Primate Specialist Group and other stakeholders was sent to the Prime Minister of Viet Nam for consideration.

Acknowledgements We thank Wildlife Reserves Singapore, The Rufford Foundation, Primate Partnership Fund, Idea Wild, Global Wildlife Conservation, Primate Conservation Inc., and the Program 562 (Grant number DTDL.CN-64/19) of Viet Nam's Ministry of Science and Technology for their support.

Author contributions Study design: all authors; fieldwork, data analysis, writing: ATN, HT-D; revision: all authors.

\section{Conflicts of interest None.}

Ethical standards This research abided by the Oryx guidelines on ethical standards.

\section{References}

Blair, M.E., Sterling, E.J. \& Hurley, M.M. (2011) Taxonomy and conservation of Vietnam's primates: a review. American Journal of Primatology, 73, 1093-1106.

Covert, H.H., Duc, H.M., Quyet, L.K., Ang, A., HarrisonLevine, A. \& BAng, T.V. (2017) Primates of Vietnam: conservation in a rapidly developing country. Anthropology Now, 9, 27-44.

KNight, T. (2019) Small steps and giant leaps - signs of hope for Vietnam's primates. Fauna \& Flora International, 19 February 2019. fauna-flora.org/news/small-steps-giant-leaps-signs-hope-vietnamsprimates [accessed 6 April 2020].

Linh, N.V., Quyen, M.V. \& Nadler, T. (2019) Rapid population increase of the Critically Endangered Delacour's langur (Trachypithecus delacouri) in Van Long Nature Reserve due to strict protection. Vietnamese Journal of Primatology, 3, 3-18.

Nadler, T. (2015) The critical status of the Delacour's langur (Trachypithecus delacouri) and the call for a national action plan. Vietnamese Journal of Primatology, 2, 1-12.

Nadler, T., Canh, L.X., Thanh, V.N. \& Quyet, L.K. (2015) Trachypithecus delacouri. In The IUCN Red List of Threatened Species 2020. dx.doi.org/10.2305/IUCN.UK.2020-2.RLTS. T22043A17958988.en [accessed 19 May 2020].

Nadler, T. \& Long, H.T. (2001) Natural History and Status Review of the Delacour's Langur (Trachypithecus delacouri) - Premilinary Report. Frankfurt Zoological Society, Frankfurt, Germany.

Nadler, T., Momberg, F., Dang, N.X. \& Lormee, N. (2003) Vietnam Primate Conservation Status Review 2002. Part 2: Leaf Monkeys. Fauna \& Flora International-Vietnam, Hanoi, Viet Nam, and Frankfurt Zoological Society, Frankfurt, Germany.

Roos, C., Boonratana, R., Supriatna, J., Fellowes, J.R., Rylands, A.B. \& Mittermeier, R.A. (2013) An updated taxonomy of primates in Vietnam, Laos, Cambodia and China. Vietnamese Journal of Primatology, 2, 13-26.

Schwitzer, C., Mittermeier, R.A., Rylands, A.B., Chiozza, F., Williamson, E.A., Wallis, J. \& Cotton, A. (2015) Primates in Peril: The World's 25 Most Endangered Primates 2014-2016. IUCN SSC Primate Specialist Group, International Primatological Society, Conservation International and Bristol Zoological Society, Arlington, USA.

Trinh-Dinh, H. \& Le, V.D. (2016) Report on Survey of Delacour's Langur (Trachypithecus delacouri) in Lac Thuy (Hoa Binh) and Kim Bang (Ha Nam), Vietnam. Fauna \& Flora International-Vietnam, Hanoi, Viet Nam.

Workman, C. (2010) The foraging ecology of the Delacour's langur (Trachypithecus delacouri) in Van Long Nature Reserve, Vietnam. $\mathrm{PhD}$ thesis. Department of Evolutionary Anthropology, Duke University, Durham, USA. 